\title{
Lateral plucking as a mechanism for elongate erosional glacial bedforms: explaining megagrooves in Britain and Canada
}

\author{
M Krabbendam \& T Bradwell \\ British Geological Survey Murchison House, West Mains Road, Edinburgh, EH9 3LA, Scotland, UK. \\ Email: mkrab@bgs.ac.uk
}

\begin{abstract}
Megagrooves are kilometre-scale linear topographic lows carved in bedrock, separated by ridges, typically in areas of largely devoid of till. They have been reported from several areas covered by Pleistocene glaciations, such as Canadian NW Territories, Michigan and NW Scotland. Here we report two previously undocumented megagroove fields from Ungava, Canada, and northern England, and present new analyses of the megagrooves from NW Scotland. This paper seeks to determine the nature of the lithological and structural controls on the occurrence and formation of megagrooves. Analysis of both geomorphological and bedrock properties shows that megagrooves are generally:

a) confined to well stratified or layered bedrock, such as (meta)sedimentary rocks with closely spaced joints, and tend not to occur on massive rocks such as gneiss or granite, or thick-bedded sedimentary rocks;

b) subparallel to palaeo-ice flow and the strike of the strata; and tend not to occur where palaeo-ice flow is at high angles to the strike of strata;

c) produced by significant glacial erosion by sustained unidirectional ice flow.

Detailed analysis of megagrooves in NW Scotland shows that neither glacio-fluvial erosion, nor differential abrasion was the dominant mechanism of formation. A mechanism, here termed 'lateral plucking', is suggested that involves block plucking on rock steps parallel to ice flow. Removal of joint-bounded blocks from such rock steps involves a component of rotation along a vertical axis. Block removal may be enhanced by a direct component of shear stress onto the vertical stoss sides. The lateral plucking mechanism results in horizontal erosion at right angles to the ice flow, and enhances the groove/ridge topography. Megagrooves are potentially useful as palaeo-ice flow indicators in areas devoid of till, and can thus complement the palaeo-ice stream datasets which are presently largely based on soft-sediment landform studies.
\end{abstract}




\section{Introduction}

Megagrooves are large scale linear topographic lows, carved in bedrock in previously glaciated areas. They occur in belts or fields ranging from $5-25 \mathrm{~km}$ wide. Individual grooves are 10-500 $\mathrm{m}$ wide, and with a length-width ratio of $>10: 1$, can range in length from one to several kilometres, and are commonly asymmetric in cross-section. To date, they have been recorded in places as far apart as the NW Territories, Canada (Smith, 1948), Isle Royale, Michigan (Zumberge, 1954), NW Scotland (Bradwell et al., 2008a), West Greenland (Roberts et al., 2009) and have been imaged at the Greenland ice sheet at the margin of the Jakobshavn Isbrae (Jezek et al. 2011). Megagrooves occur in areas with little or no till cover, and should not be confused with 'megaflutes' or 'megascale glacial lineations', which are elongate ridges composed of unlithified sediments, commonly associated with (palaeo) ice streams (e.g. Boulton \& Clark, 1990; Stokes \& Clark, 1999, 2001; Woodward \& King, 2009). Nevertheless, Stoker \& Bradwell (2005) and Bradwell et al. (2008a) argued that, on the basis of high length-width ratios of megagrooves and other criteria, megagrooves were similarly formed by fast, unidirectional ice flow at the base of palaeoice streams. The above examples - and two newly identified fields from England and Canada that we report below - are carved in bedrock that posses a strong layering, such as sedimentary or metasedimentary rocks. Their formation thus appears to be strongly controlled by bedrock lithology and structure. Zumberge (1954) and Roberts et al. (2009) implied that megagrooves are primarily formed by differential abrasion rates of strata or layers of different lithology and hardness. However, the megagrooves in NW Scotland occur in a very uniform stratigraphy, in which all strata have similar composition (Bradwell et al., 2008a, and see below). Therefore, differential abrasion cannot satisfactorily explain megagroove formation, and the formation mechanism remains elusive. The challenge is to elucidate the controls of particular bedrock properties on the specific subglacial erosion mechanism(s) that led to megagrooves formation. Previous studies have shown that bedrock properties such as hardness and joint spacing affect abrasion and plucking (e.g. Boulton, 1979; Rastas \& Seppällä, 1981; Gordon, 1981; Sugden et al., 1992; Rea,1994; Glasser et al. 1998; Sklar \& Dietrich 2001; Dühnforth et al. 2010); and this study builds onto these studies.

In this paper we report two new megagroove localities in northern England and Ungava, Canada, and describe their relation to overall bedrock geology, such as large-scale lithological differences and large-scale changes in bedrock strike. We then describe a detailed study of the landforms and bedrock properties of the Ullapool Megagrooves in NW Scotland, in order to assess the control of outcrop-scale bedrock properties on megagroove formation. Based on this analysis we suggest a formation mechanism, involving lateral plucking, as opposed to abrasion. We also discuss implications of the occurrence of megagrooves for the reconstruction of ice flow patterns in formerly glaciated terranes

\section{Methods}

The Ungava and Isle Royale megagrooves in Canada were studied by remote sensing methods using Landsat satellite imagery. Megagrooves in Britain were studied using hill shaded images, derived from the NEXTMap Digital Terrain Model (DTM) (@ Intermap Technologies), which has a horizontal and vertical resolution of 5 and $1 \mathrm{~m}$ respectively. All images used here have NW illumination. Geomorphogical 
properties, such as megagroove spacing, length and length/spacing ratio of megagrooves and length/width ratios of lakes were measured and are presented in Table 1.

In the NW Highlands, traditional geomorphological methods were used to describe the mediumscale landforms. Glacial striae in the Ullapool area were taken from the original 1:10 560 standard geological maps $(1880-1900)$ in the British Geological Survey archive. About 25 striated localities were revisited in the field, where the striae dataset was found to be reliable. Bedrock geological data come from British Geological Survey maps.

In the NW Highlands, a detailed field study was performed to analyse the links between erosional bedforms and outcrop-scale bedrock properties. An important issue is which bedrock property is relevant (and can be measured efficiently in the field) to what erosion mechanism (Augustinus, 1991). According to Iverson (1991a) glacial abrasion is dependent on relative clast-to-bed hardness and, for removal of multi-grain fragments, the tensile strength of the bed. In contrast, Boulton (1979) emphasised the absolute hardness of the bed, arguing that in many cases the clasts are similar in lithology to the bed. Sklar \& Dietrich (2001) showed experimentally that resistance to (fluvial) abrasion is indeed dependent on absolute hardness of the bed, as well as on relative clast-to-bed hardness. They also showed a good correlation between fluvial abrasion resistance and tensile strength for a wide range of rock types. For this study we performed Schmidt Hammer rebound values as a semi-quantitative proxy for abrasion resistance. Over a range of rock types, Schmidt Hammer rebound values correlate well with tensile strength, uniaxial compressive strength and abrasion hardness (Deere \& Miller 1966; Augustinus, 1991, Aydin \& Basu, 2005). The Schmidt Hammer test is an efficient, non-destructive method that can be carried out quickly in the field on a large number of sample sites. Only fresh, preferably striated, surfaces were measured. All measurements were taken more than $20 \mathrm{~cm}$ from joints and more than $1 \mathrm{~m}$ away from edges, to minimise any edge effects (e.g. Viles et al., 2010). The occurrence of lichen significantly lowers the Schmidt hammer values, hence all surfaces were polished prior to measurement to remove lichen.

Concerning plucking, it may be possible to fracture unjointed bedrock if differential stresses on a rock step are very high (e.g. Hallet, 1996), but these seem to be exceptional circumstances (see Gordon 1981 for an example). Joints represent such a significant mechanical weakness compared to unfractured rock, that the occurrence of joints in most cases control whether or not plucking occurs (Mathes, 1930, $p$ $90 \mathrm{ff}$; Rea \& Whalley, 1996), and this is borne out by a great number of field studies describing links between joints and plucking (e.g. Mathes 1930; Rastas \& Seppällä 1981, Gordon 1981, Sugden et al. 1992; Rea 1994; Dühnforth et al. 2010). We note here that joints are amongst the most common geological structures on Earth and are ubiquitous in well-stratified rocks in non-glaciated and glaciated regions alike. They are generally caused by non-glacial processes such as tectonic strain, sedimentary loading and erosive unloading and cooling (e.g. Davis \& Reynolds, 1996; Rogers \& Engelder, 2004; Peacock, 2004). Consequently we assume that the joints in the study areas are in essence pre-glacial (eg. Laubach \& Diaz-Tushman, 2009), although sub-horizontal (bedding-parallel) joints may have been further opened by repeated glacial loading and unloading.

For our joint spacing analysis we first measured joint spacing and orientation on a (subhorizontal) bedding plane to establish the orientation of the dominant joint sets, using a geological compass ('area method' - see for instance Davis \& Reynolds, 1996). Joint spacing was subsequently measured along 
transects of $10 \mathrm{~m}$ or longer of continuous cliff exposures, at approximate right angles to the dominant joint sets ('line method' - Davis \& Reynolds, 1996). Only open joints were measured: although cemented joints (veins) were noted, these rarely appeared to be continuous or represent mechanical weaknesses. Bedding thickness was measured on subvertical exposures with a height range of $3-100 \mathrm{~m}$. The definition of a bedding plane as a mechanical discontinuity is somewhat subjective. Here, we measured only those bedding planes that either coincide with a joint (bedding plane joints) or which contain a significant concentration of mica or clay minerals, and hence represent a clear mechanical weakness.

\section{Results}

\section{Megagrooves of the Ungava Peninsula, Canada}

On the Ungava Peninsula in northern Quebec, east of Hudson Bay, a $20 \times 250 \mathrm{~km}$ area of strong ENEtrending lineations is clearly visible on Landsat satellite imagery (Figure 1a, 2). The lineations are composed of rock ridges separated by elongate grooves. Many grooves are elongate closed rock basins and contain elongate lakes, up to $15 \mathrm{~km}$ long,. Till cover is patchy to non-existent over large areas (e.g. Fulton, 1995). Data relating to groove length, spacing and lake elongation ratio are presented in Table 1. The ridge/grooves are strongly elongate, but not entirely straight: they clearly follow strike-swings of bedrock strata, and locally tectonic folds can be seen (Figure 2). On either side of this belt is a very different terrain, comprising hundreds of small lakes and hillocks lacking a pronounced preferred orientation or elongation, which can be described as a 'cnoc-and-lochan' or 'areal scour' landscape (e.g. Sugden, 1978; Rea \& Evans, 1996). The groove/ridge terrain coincides with the Cape Smith Fold Belt, a belt of sedimentary and metasedimentary strata that includes sandstone, conglomerate, semipelite, pelite, quartzite and mafic and ultramafic volcanic rocks, and possessing a pronounced layering of original sedimentary stratification as well as tectonic foliation and thrust faults (St-Onge et al., 1986, 1988, 1993; Goodwin, 1991). The strata and thrust faults within this belt strike WSW-ENE and dip $10-40^{\circ}$ to the north. In contrast, the 'cnoc-an-lochan' landscape coincides with rocks of the Superior Province, comprising crystalline gneisses of igneous origin and granitoid intrusions (Goodwin, 1991; Wheeler et al., 1996). During the Pleistocene, the Ungava area was repeatedly glaciated. Most authors argue for eastward palaeo-ice stream through the Hudson Strait (Fig 1a) some $100 \mathrm{~km}$ to the north of the Ungava megagrooves (Dyke \& Prest, 1987; Dyke et al., 1989, Laymon, 1992; De Angelis, 2007). The direction of ice flow in the Ungava peninsula is complex and appears to have changed over time. Vincent (1989) and De Angelis (2007) show a number of ENE-directed ice flow indicators as well as eskers, broadly parallel to the strike of the Cape Smith Belt. St-Onge et al. (1993) document cross-cutting striae, with an older phase of eastward ice flow parallel to the Cape Smith Fold Belt, and a later phase of northward directed ice flow (possibly related to deglaciation, see Dyke \& Prest, 1987; Dyke et al., 1989) at high angles to that belt. Thus at least during some stages of glaciation, ice flow was parallel to the megagrooves and the Cape Smith Fold Belt. 


\section{Megagrooves of the Tyne Gap, northern England}

The Tyne Gap in northern England is an east-west trending breach in the watershed across the 'spine' of Northern England bounded to the north and south by plateaux c. 2-300 m higher than the breach (Figure 1b). Ice flowed eastward during most phases of the Main Late Devensian glaciation (Livingstone et al., 2008).

The bedrock of the area is dominated by a sequence of alternating strata of Carboniferous sandstone, mudstone and limestone, with thin coal beds. Units of sandstone and limestone are 5-20 m thick. Individual limestone beds are 0.4-1 m thick; individual sandstone beds $0.5-2 \mathrm{~m}$ thick, whilst bedding in the more mudstone rich units is thinner (e.g. British Geological Survey, 1980a; Young \& Lawrence, 2002). There is a well developed conjugate joint system, on a similar scale as the bedding, so that the rock discontinuities delineate cuboid blocks. In addition, the 30-50 m thick dolerite Whin Sill extends across the area, broadly parallel to surrounding strata. Jointing in the Whin Sill dolerite is either cuboid or columnar, with a typical joint spacing of $0.5-1.5 \mathrm{~m}$. In the Tyne Gap, the strata dip $10-20^{\circ}$ to the SSE, and have a ENE-WSW strike (Figure 3a). Towards the NE in the low-lying Hallington area, there is a pronounced strike swing (Figure 1b): strata strike NNE to north, and dip c. 5-10 $0^{\circ}$ to the east (British Geological Survey, 1980a). The strike here is at high angles $\left(70-90^{\circ}\right)$ to the eastward ice flow (Figure $3 b)$, with beds dipping the same direction as the ice flow.

In the Tyne Gap, a well-defined ridge/groove landscape occurs in a belt 3-6 km wide and c. $20 \mathrm{~km}$ long (Figure 3a). The ridge/grooves are strongly asymmetric in cross-section, with steep north-facing walls, and gentle south dipping 'flats/benches'. In general the grooves are capped by sandstone or the Whin Sill, suggesting these are more resistant to erosion than the limestone units. Individual ridges are $1-$ $4 \mathrm{~km}$ long, whilst the spacing of the ridges varies between $100-400 \mathrm{~m}$ (see table 1). Ridge-groove amplitude varies between 5 and $20 \mathrm{~m}$. Till cover is patchy and confined to the grooves (British Geological Survey, 1980b).

The Hallington area to the NE is characterised by more extensive till cover (British Geological Survey, 1980b). Numerous drumlins and crag-and-tails, indicate east to ENE directed ice flow (Figure 3b, see also Livingstone et al., 2008), and no megagrooves occur. Some elements of the north-south striking strata are just discernible on the DTM, as some bedrock features do locally appear from underneath the till cover, suggesting a subdued stepped topography beneath the till. In the eastern part of the image, however, crag-and-tails show that the bedrock steps are strongly discontinuous. Over large areas this stepped topography is absent..

\section{Megagrooves, North West Highlands, Scotland}

The megagrooves at Ullapool in the NW Highlands of Scotland have been described by Bradwell et al. (2008a), so only a summary is given here. The megagrooves trend east-west and occupy an area of 8 by $10 \mathrm{~km}$, largely devoid of till. They occur within a large breach or gap (c. $400 \mathrm{~m} \mathrm{OD}$ ) across the main watershed, between the mountain massifs of Ben More Assynt (max 960 m OD) in the north and Beinn Dearg Massif ( $\max 1000 \mathrm{~m}$ OD) to the south (Figure 1c). Glacial striae, together with the overall glacial setting, show overall east-to-west ice flow into the Minch (Figure 4a, 5a). Stoker \& Bradwell (2005) and Bradwell et al. (2008a) suggest the megagrooves form part of a footprint of a topographically constrained 
palaeo-ice flow that flowed westward and joined the Minch Paleo ice stream, which flowed farther west and north-west to the Sula Sgeir Fan, a large glacio-marine fan at the continental margin. In the study area, ice flowed westward across three different rock types: from east to west the Morar metasandstone, a narrow strip of Cambrian Quartzite and Torridon sandstone (Figure 4a). The megagrooves are only well developed on the Morar metasandstone, and thus indicate a strong link between megagroove formation and lithology.

\section{Torridon Sandstone}

The Torridon sandstone (Applecross Formation) is an unmetamorphosed, coarse, red sandstone with occasional pebble conglomerate and siltstone beds. The Torridon Group is a remarkably uniform sequence, with little stratigraphical variation over an estimated stratigraphical thickness of 4-5 km (Stewart, 2002; Park et al., 2002). The sandstone is arkosic, comprising quartz and feldspar in a matrix of clay and hematite (e.g. Stewart, 2002), and it is the softest rock in the area (Schmidt hammer value $R \sim 46$, see Table 2). Beds are thick ( $0.8-2.2 \mathrm{~m}$ interquartile range see Table 2 and Figure $6 \mathrm{a})$. Strata dip c. 5-10 $0^{\circ}$ to the east. The joint spacing is c. $1.5-5.5 \mathrm{~m}$; two joint sets are dominant: a NNE-SSW and a NW-SE trending set (Figure $5 b$ ). Blocks can be defined as delineated by bedding planes and joints: the average volume of the joint-bounded blocks is c. $9 \mathrm{~m}^{3}$. Compared with the two other rock types to the east, the Torridon sandstone is relatively soft, but massive over many cubic metres.

\section{Cambrian quartzite}

The Cambrian Quartzite (Eriboll Formation, comprising the Basal Quartzite Member and the Pipe Rock Member, e.g. Prigmore \& Rushton, 1999) comprises medium fine grained feldspathic quartzite, with strata dipping $10-12^{\circ}$ to the east. The median bed thickness is $0.16 \mathrm{~m}$. The rock is the hardest of all in the study area $(R \sim 61$, table 2$)$ but has abundant, closely spaced joints $(0.13-0.47 \mathrm{~m})$. Again, two joint sets are dominant: a WNW-ESE and a NNE-SSW trending set (Figure $5 \mathrm{c}$ ). The average block volume is $0.013 \mathrm{~m}^{3}$, the smallest of all rocks tested. This small block volume is confirmed by the widespread presence of small $\left(<0.02 \mathrm{~m}^{3}\right)$ erratics on the Torridon sandstone to the west.

\section{Morar metasandstone.}

The Morar rocks comprise metamorphosed sandstone and minor siltstone. It shares the same origin as the Torridon Sandstone and has a similar stratigraphic thickness $(>3 \mathrm{~km})$ and uniformity (Krabbendam et al., 2008). However, relevant bedrock properties have been strongly modified due to deformation and metamorphism to c. $500^{\circ} \mathrm{C}$ (e.g. Winchester, 1974; Fettes et al., 1985) associated with Caledonian orogenesis. The hardness has increased to $\mathrm{R} \sim 52$, due to pervasive recrystallisation. Bed thickness is dramatically thinned, down to c. $15 \mathrm{~cm}$ (Table 2, Figure 6b). In addition, there is well developed mica foliation parallel to bedding, so that rock is easily cleaved along bedding planes. Joint spacing is $0.20-0.9$ $\mathrm{m}$, with three joint sets present along NNE-SSW, ENE-WSW and NW-SE trends (Figure $5 \mathrm{~d}$ ). The average block volume is c. $0.03 \mathrm{~m}^{3}$. Because of the inherited stratigraphic uniformity, all metasandstone has similar properties over the entire megagroove field. There are no lithological differences between the ridges and the grooves. 
The bedding/foliation planes dip gently $\left(<15^{\circ}\right)$. Although variable, the strike of the bedding/foliation is broadly east-west, subparallel to ice flow, over much of the megagroove field (Figure $4 \mathrm{~b}$ ). In the southern part of the megagroove field, beds dip very gently $\left(<10^{\circ}\right)$ to the SE or east (Figue $4 \mathrm{~b}$ ). At such low dips, however, more important is the orientation of the hill slopes. If a local hill slope trends east-west, as is the case here, the intersection of very shallow dipping bedding/foliation with low dips is also broadly east-west, independent of the strike of the bedding.

\section{Megagroove and bedrock structure}

The Ullapool megagrooves are between 1000 and $2500 \mathrm{~m}$ long, 2 - $20 \mathrm{~m}$ deep and 50 - $120 \mathrm{~m}$ wide (Table 1). Megagroove spacing is $100 \mathrm{~m}$ in the densest areas (Figure 7, 9, Table 1 - see also Bradwell et al., 2008a). The megagroove field occurs across the present-day watershed, with many megagrooves formed by ice flowing 'uphill' against the local topographic gradient (Figure 4a). Three types of megagroove occur, with different cross-profiles (see also Bradwell et al., 2008a); Asymmetric, V-shaped and parabolic megagrooves: some individual megagrooves change their cross-profile along their length. $A$ minority of grooves contain small elongate lakes and have thus evolved into elongate rock basins with a minor component of overdeepening along their long axes (Figure 8a).

Asymmetric megagrooves are by far the most common. They have a $2-15 \mathrm{~m}$ high steep rock wall and a gently $\left(<15^{\circ}\right)$ dipping flat floor parallel to the local bedding/foliation. The 'flats' are generally smooth bedrock dip slopes. The rock walls are generally rugged and blocky, characterised by rectangular blocks varying from 0.2 to $0.8 \mathrm{~m}^{3}$, delineated by the joints and bedding (Figures $6 a, 8 b, c, d$ ). At one locality, $\mathrm{a} \sim 0.5 \mathrm{~m}^{3}$ block was found to be partially rotated out of a low rock wall (Figure $8 \mathrm{c}, \mathrm{d}$ ). It is possible that some post-glacial block loosening occurred by freeze-thaw action, although it is difficult to see how this could lead to the apparent rotation around a vertical axis. At any case, this particular block illustrates the possibility of rotation around a vertical axis during subglacial erosion, as discussed below.

The relationship with the bedrock structure is most obvious in the asymmetric megagrooves. On figure $4 \mathrm{~b}$, the strike-and-dip symbols of the bedding/foliation are plotted over the NEXTMap shaded relief image. In the northern half of this area, the bedding/foliation strikes broadly east-west, subparallel to ice flow: it is here that megagrooves are best developed. Furthermore, on the cross-section (Figure 9) it can be seen that the megagroove density is highest on the north-facing slopes, where the angle of intersection between bedding and slope is greatest. On south facing slopes, where the angle of intersection between bedding and slope is small, megagrooves are rare. On some local dip slopes (where bedding and slope are parallel) megagrooves are absent (marked 'dipslope' in the SE corner of Figure 4b). Groove spacing is therefore strongly dependent on the intersection of bedding/foliation with the surface slope.

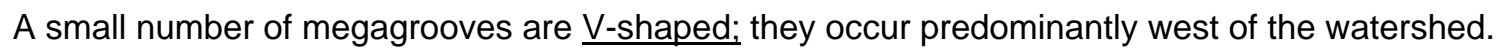
Asymmetric megagrooves commonly change from parabolic to V-shaped as they cross the watershed; suggesting a component of subglacial meltwater erosion. A small number of parabolic megagrooves occur, these are by far the biggest grooves (Bradwell et al., 2008a).

Erosional landforms of the Torridon sandstone comprise whalebacks and elongate roches moutonnées, with abundant striae (where unaffected by post-glacial weathering) and longitudinal P-forms 
(see also Bradwell et al., 2008a; Bradwell, 2010; Krabbendam \& Bradwell, 2010). Strata dip to the east, against the palaeo-ice flow: we suggest that this arrangement is favourable for the formation of classic roches moutonnées (see also Gordon, 1981; Rea, 1994). Some lee-side plucking has occurred exploiting the NNW trending joint set. This joint set is widely spaced and consequently lee-side plucking is relatively rare, and roches moutonnées are elongate and commonly transitional with whalebacks (Figure 6a). Overall, it appears that abrasion was dominant over plucking on the Torridon Sandstone (Krabbendam \& Bradwell, 2010) and that the particular bedrock properties prevented the formation of regularly spaced megagrooves.

\section{Discussion}

\section{Large-scale controls on megagroove occurrence}

The analysis of Ungava shows that megagrooves occur in the metasedimentary rocks of the Cape Smith Belt, but not in the adjacent gneisses and granites of the Superior Province, which instead developed a very different landscape of aerial scour. The metasedimentary rocks posses a pronounced layering that is consistent over tens of kilometres; in contrast, the gneisses of the Superior Province are massive rocks, without a pronounced or consistent layering. Both landscapes contain closed rock basins (lakes) suggesting in both cases a significant component of glacial erosion (e.g. Sugden \& John 1976). The lakes in the Cape Smith Belt, however, are strongly elongate, whilst those on the Superior Province are not (Figure 2, Table 1). The precise ice-flow in the area is ambiguous (and may well have changed during different phases of the evolution of the Laurentide Ice Sheet), but it appears that at least during some stages of glaciation, flow was parallel to the strike of the Cape Smith Belt. What is remarkable is the difference in landscapes formed in an area of generally low overall relief. Thus, the Ungava example shows that megagrooves have a strong preference to develop in layered bedrock and do not form in the more massive, poorly layered bedrock of the Superior Province.

The Tyne Gap / Hallington areas in northern England show the broad control of bedrock strike on megagroove occurrence. The bedrock type in both areas is the same, but the relationship between strike and ice flow is different. In the Tyne gap, ice flow was subparallel to the strike of the strata and pronounced megagrooves occur, whilst in the Hallington ice flow was at high angles to the bedrock strike and megagrooves are absent. The absence of megagrooves in the Hallington area can potentially be explained in several ways. Firstly, megagrooves could be wholly pre-glacial features, subsequently covered by till. However, some subdued bedrock steps are visible on the Hallington area, for instance west of the Whin Sill (hatched), elsewhere crag-and-tail features occur. This suggests that till cover is not sufficiently thick to cover a pronounced megagroove landscape (Figure 3). More likely is that some subdued bedrock steps existed prior to the last glaciation (possibly formed by non-glacial processes - see below), but were enhanced in the Tyne Gap area by glacial erosion to form the megagrooves, whilst being degraded in the Hallington area, by erosion off the crests and till deposition in the hollows.

We suggest that if both bedrock type and ice flow are similar, the angle between ice flow and bedrock strike forms an important control on subglacially generated landforms. 


\section{Formation mechanism of megagrooves}

Asymmetric megagrooves are the most common type of megagroove, and it is likely that other megagroove types ( $\mathrm{V}$-shaped and parabolic) are modifications of the asymmetric megagrooves. We therefore first attempt to explain the asymmetric megagrooves before discussing the other types. Asymmetric megagrooves have similarities with the stepped slope/escarpment landscape of many slopes subjected to subaerial weathering and erosion (e.g. cuesta landscapes); therefore the possibility of a nonglacial origin must be considered. However, a non-glacial origin as the main formation mechanism is rejected because of:

1) the strong parallelism of ice flow and strike of strata, and the absence of megagrooves in areas were this parallelism does not occur;

2) the scarcity of products of non-glacial, subaerial weathering/erosion such as scree or grus;

3) the fact that the 'flats' commonly dip against the main topographic slope, and that elongate rock basins occur; features not typical of cuesta landscapes.

It remains possible, however, that a certain amount of subaerial weathering and erosion occurred during interglacials, resulting in a stepped landscape, which was stripped and further enhanced by subsequent glacial erosion. This is especially the case for rock sequences composed of different rock types that would be expected to experience differential subaerial weathering (Tyne Gap, Ungava, Isle Royale). However, the stratigraphic uniformity of the Morar metasandstone precludes such differential weathering for the NW Highlands.

Within the subglacial environment, erosion occurs potentially by three mechanisms: subglacial meltwater, abrasion and plucking. There are a number of glacial meltwater channels in the Ullapool area, commonly with V-shaped cross-profile. These are either i) developed along NE-SW trending faults and fractures at high angles to the megagrooves (Figure 4b), or ii) occur just west of the present-day drainage divide and appear to represent megagrooves modified by meltwater (see more below). Within the asymmetric megagrooves there is no evidence of subglacial-fluvial erosion. Subglacial meltwater had its own drainage system, largely independent from the megagrooves, and hence subglacial-fluvial erosion is rejected as the primary formation mechanism of megagrooves (see also Bradwell et al., 2008a). We therefore suggest that megagrooves are predominantly formed by glacial erosion. The focus then shifts to understanding the prime mechanism: abrasion or plucking.

\footnotetext{
Abrasion

Landforms associated with abrasion include glacial striae, whalebacks, longitudinal P-forms and other rounded, streamlined bedforms (e.g. Benn \& Evans, 1998; Glasser \& Bennet, 2004). These features are ubiquitous on the Torridon Sandstone, suggesting that this rock type was eroded largely by abrasion, with subordinate plucking on the lee-side of relatively rare roches moutonnées, controlled by widely spaced joints (see also Bradwell et al., 2008a; Krabbendam \& Bradwell, 2010). Abrasion-related landforms are expected in the Torridon Sandstone, as this is a relatively soft rock $(R \sim 45)$ that was abraded by ice carrying basal debris that is considerably harder (Cambrian quartzite and Morar metasandstone, $\mathrm{R} \sim 60$ and $R \sim 55$ respectively, see also Krabbendam \& Bradwell , 2010). In contrast, abrasion-related landforms are rare to absent on the Morar metasandstone. In the NW Highlands, differential abrasion of different
} 
lithologies cannot have formed the megagrooves, since the grooves and ridges are exactly the same lithology. We therefore conclude that abrasion is not the primary formation mechanism of megagrooves.

\section{Lateral plucking and asymmetric megagrooves}

Subglacial plucking is potentially a three-step process, involving 1 ) fracturing of bedrock; 2 ) loosening of a block from bedrock, followed by 3) entrainment of the block in ice (e.g. Röthlisberger \& Iken, 1981; Rea, 1994; Hallet, 1996; Benn \& Evans, 1998). In unfractured bedrock, fracturing is the likely rate-controlling step (e.g. Hallet 1996) and may occur only rarely, limiting the effectiveness of plucking in such rocks. However, if pre-existing joints exist (as they commonly do) and delineate joint-bounded blocks, step 1 has already been achieved by pre-glacial fracturing. The forces resisting block loosening (step 2 ) are then the friction along joint surfaces and the cohesion of any cement present. These resisting forces are much lower than the intact rock strength, and block removal becomes much easier (Rea, 1994). This is consistent with numerous studies showing qualitatively a strong relationship between joints, plucking and resultant landforms (Mathes, 1930; Haynes, 1968; Rastas \& Seppälä, 1981; Gordon, 1981; Sugden et al., 1992) and local erosion rates (Dühnforth et al., 2010).

Most experimental and theoretical studies on plucking consider the case of a classic roche moutonnée (Figure 10a), with a lee-side rock step trending at right angles to ice flow, and 'beds' dipping against the ice flow (e.g. Röthlisberger \& Iken, 1981; Rea 1994; Rea \& Whalley, 1996; Hallet, 1996; Cohen et al., 2006). The formation of cavities, induced by ice flow, in the lee of a rock step is regarded as crucial for plucking to proceed. The cavity causes differential stresses to develop, because the top surface of the block is subjected to the ice overburden pressure $\left(\sigma_{a}\right.$ in Figure 10a) whilst the lee side is subjected only to the water pressure within the cavity $\left(\sigma_{c}=P_{w}\right.$, see Figure 10a). These differential stresses may be further enhanced by fluctuating water pressure in the cavity (Röthlisberger \& Iken, 1981; Iverson, 1991b; Cohen et al., 2006). In addition there is a component of drag parallel to ice flow, which results in a shear stress acting on the top surface $\left(\tau_{\mathrm{a}}\right)$. This shear stress increases with increasing angle $\boldsymbol{\alpha}$ (up to a value of $45^{\circ}$ ) between the ice-flow vector and the rock surface (Hallet, 1996; Rea \& Whalley, 1996). Depending on the amount of debris in the basal ice, there may also be a significant component of frictional drag acting parallel to ice flow (Cohen et al. 2005).

Once a joint is opened up, block removal may be further aided by ice flowing into open cracks behind and adjacent to the block, pushing it out into the cavity (Anderson, 1982; Rea, 1994). In the case of lee-side plucking, block removal mainly involves horizontal translation in the direction of ice flow (Figure 10a). The overall direction of erosion is opposite to ice flow, analogous to headward retreat of a back scarp.

We suggest here that formation of asymmetric megagrooves requires a particular arrangement of bedrock discontinuities (bedding + joints) with respect to ice flow that results in a special case of plucking, from rock-steps that are oriented sub-parallel to ice flow (Figure10b). We term this process here "lateral plucking", to distinguish this from the better studied lee-side plucking. The envisaged process is as follows.

- Ice flows along a steep wall; the wall is jagged with rectangular joint-bounded blocks, forming substantial protuberances; 
- Ice flow along these protuberances causes cavities to develop behind the vertical lee sides (marked c on Figure 10b);

- Initial block loosening occurs and the block translates and rotates around a vertical axis. As rotation proceeds, more surface area of the block is exposed to moving ice and the forces on the block $\left(\tau_{b}\right)$ increase until the block is loosened completely. It either falls in a cavity, or is directly entrained in ice and transported;

- More blocks, above and/or below the first block, become available for plucking, and the process of block loosening is repeated;

- In contrast, ice-flow along the flat megagroove floor is smooth. There are no large-scale protuberances, no stoss- or lee sides, and plucking will be strictly limited. Blocks cannot be rotated out of the 'flat', as they are packed tightly together. Glacial erosion occurs only by abrasion;

- As a result there is strongly differential erosion: slow vertical erosion on the flat floor controlled by abrasion, and faster erosion acting laterally on the rock step controlled by lateral plucking (Figure 10b, c).

- If the starting point is a smooth slope (step 1 in Figure 10c), or only poorly defined grooves (step 2 in Figure 10c), rock steps develop further, resulting in an increase in lateral ruggedness, as erosion progresses. Once the entire subglacial surface either exist of bedding-parallel flats or of rock steps, a steady state grooved surface will probably be reached (steps 5 and 5 ' in Figure 10c).

In many aspects, lateral plucking is simply normal lee-side plucking turned $90^{\circ}$ on its side (Figure $10 \mathrm{~b}$ ). However, there are a number of differences including:

- Block removal involves rotation around a vertical axis as opposed to bedding-parallel translation;

- The overall direction of erosion is at right angles to ice flow;

- The stresses acting upon the block are somewhat different. All other things being equal, the frictional drag on the top surface would be similar, as is the component of ice overburden pressure acting on that surface $\left(\sigma_{a}\right.$ in Figure $\left.10 a, b\right)$. However, the shear stress acting on the vertical stoss face $\left(\tau_{\mathrm{b}}\right)$ could be higher than the acting shear stress $\tau_{\mathrm{a}}$ in normal lee side plucking. This is because during lateral plucking, high values of angle $\alpha$ (see Figure 10) and hence high shear stresses $\tau_{b}$ may develop on the vertical stoss side faces along the rock steps (depending on the orientation of the joints with respect to ice flow). However, most of the bed surface comprises flat floors and is smooth, with a low angle $\boldsymbol{\alpha}$ and low shear stress $\tau_{a}$, facilitating fast ice flow. The combination of overall fast, unimpeded ice flow, with localised high values of angle $\boldsymbol{\alpha}$ and shear stress $\tau_{\mathrm{b}}$, may result in faster localised (lateral) erosion rates. In classic lee-side plucking high values of angle $\alpha$ would result in a very rough bed, possibly slowing ice flow (e.g. Iken, 1981), and hence cause lower shear stresses and lower plucking rates.

- The top surface of the block is subjected to a vertical component of the ice overburden pressure $\sigma_{\mathrm{a}}$. This is translated onto the joint surface at the base of the block and increases the resisting friction along that surface, similar to the situation in lee side plucking (eg. Rea 1994). However, in 
lateral plucking the friction along that surface is overcome by a combination of translation and torsion, whilst in normal lee side plucking only translation occurs.

- Further differences may lie in the different shape of the cavities and complicated, heterogeneous ice flow in the vicinity the rock step. What the effects of these factors are on the plucking process is currently not known.

The processes by which the flat-step geometries were established in the first place are conjectural. In areas of different rock types (e.g. Tyne Gap, Ungava), differential subaerial weathering or differential glacial abrasion may have initiated an incipient flat-step geometry (for instance step 2 in Figure 10c), which was subsequently enhanced by lateral plucking. Megagroove spacing in these cases would be primarily controlled by the thickness of the different rock formations. However, this process cannot be invoked for the Ullapool megagrooves. It is here likely that lateral plucking first started on those slopes where the angle between bedding and topographic slope was greatest and where the highest concentration of joints per surface area occurs. This is supported by the fact that the greatest concentration of megagrooves occur on north-facing slopes, with fewer megagrooves on south-facing slopes, where the angle between topographic slope and bedding/foliation is small (Figure 9).

\section{Development of V-shaped and parabolic megagrooves}

Most V-shaped megagrooves in the NW Highlands occur west of the watershed. Numerous individual megagrooves have an asymmetric cross-section in the east, which changes to a V-shaped profile as they cross the watershed. V-shaped megagrooves are most likely formed by modification of pre-existing asymmetric megagrooves by sub-glacial meltwater, with a strong component of localized, vertical erosion (Figure 10d). In the NW Highlands, the ice divide occurred well east of the watershed (Bradwell et al. 2008b). In such a situation, subglacial meltwater could pond up between the ice divide and the watershed, with relatively low flow rates. Higher flow rates would be expected were the meltwater would flow over the watershed (possibly periodically); resulting in higher rates of erosion by that meltwater. This could well explain the prevalence of $\mathrm{V}$-shaped megagrooves just west of the watershed.

The (relatively rare) parabolic megagrooves commonly display a component of overdeepening along their long axes. Erosion direction was both vertical and lateral to both sides. Again, some individual megagrooves portray both asymmetric and parabolic profiles along their length, and the parabolic megagrooves are seen as a modification of pre-existing asymmetric megagrooves. This modification could have been the result of either i) a component of downward directed abrasion, or ii) a combination of (periodic) subglacial meltwater erosion producing a $\mathrm{V}$-shaped channel, subsequently modified by lateral plucking on both sides of the channel (Figure 10e).

\section{Implications for palaeo-ice flow patterns}

Megagrooves occur in a variety of places, always coincident with the occurrence of well-stratified or layered rocks, and their formation is strongly controlled by bedrock structure. In all cases where palaeoice flow is known, they occur sub-parallel to ice flow, and it appears that sustained uni-directional ice flow is required to produce megagrooves (e.g. Bradwell et al., 2008a; Roberts et al., 2009; Jezek et al. 2011). 
This suggests that megagrooves can potentially provide constraints on palaeo-ice flow directions, and assist in reconstructing flow patterns of Pleistocene ice sheets (Stoker \& Bradwell 2005; Bradwell et al. 2008b). This may be particular helpful in areas devoid of soft-sediment ice flow indicators such as drumlins or megascale glacial lineations. The advantage of megagrooves is that, unlike glacial striae, they can be detected using remote sensing techniques. However, their interpretation is less straightforward than that of soft sediment ice flow indicators such as those reported by Stokes \& Clark $(1999,2001)$ and De Angelis \& Kleman (2007). As an erosional form, it is possible that megagrooves are formed over more than one glaciation (see Glasser \& Bennet, 2004, for general discussion on the use of erosional landforms for ice-flow reconstructions). In topographically constrained ice streams, it is likely that large-scale topographic gaps such as at Ullapool and the Tyne Gap constrained ice streams repeatedly during multiple glaciations. In these cases, megagrooves are a good indication of overall ice flow direction, but it remains unclear how much erosion occurred during the last glaciation relative to previous ones.

The significance of megagrooves in flatter areas such as the Canadian Shield in which topographically unconstrained ice streams are known to have operated (e.g. Stokes \& Clark, 1999, 2001, De Angelis \& Kleman, 2007), remains difficult to ascertain. Firstly, it is possible that the strike of the megagrooves does not exactly match the direction of palaeo-ice flow: a deviation of $10-20^{\circ}$ is probably possible. Secondly, the boundaries of a field of megagrooves may be more controlled by lithological factors (e.g. Ungava) than by glaciological ones, making it difficult to constrain the size of a palaeo-ice stream. However, careful analysis of megagrooves, combined with other ice flow indicators, can be worthwhile in areas devoid of depositional ice-flow indicators (e.g. Bradwell et al., 2008a; Roberts et al., 2009).

\section{Conclusions}

Megagrooves are a more common occurrence on deglaciated bedrock terrains than previously thought. They occur in northern England and Ungava, Canada, in addition to previously reported occurrences in NW Scotland, Michigan and the Canadian NW Territories and West Greenland. Megagrooves occur on well-stratified or layered bedrock with closely spaced joints, such as thin-bedded (meta)sedimentary sequences. They do not occur on massive crystalline rocks or thick-bedded sedimentary rocks. Megagrooves occur subparallel to the strike of the bedrock strata or layering, and subparallel to the palaeo-ice flow. In northern England, a till-covered terrain occurs where ice flowed at right angles to the strike of strata, even though similar strata parallel to ice flow nearby show well-developed megagrooves. Megagrooves appear not to form where ice flowed at right angles to the strike of strata.

Field analysis of megagrooves in NW Scotland shows that neither glacio-fluvial erosion, nor differential abrasion, are plausible primary formation mechanisms. Instead, a model involving plucking is suggested. This model involves plucking of blocks delineated by pre-existing joints and bedding, along rock faces subparallel to ice flow; termed here 'lateral plucking'. In contrast to classic lee-side plucking of roches moutonnées, lateral plucking involves a component of block rotation around a vertical axis; it is likely that flowing ice exerted a stronger component of direct shear stress upon the blocks being removed. Lateral plucking results in subhorizontal erosion at right angles to ice flow, and enhances the steep walls of 
the megagrooves. The formation of megagrooves is therefore strongly controlled by bedrock properties. If these controls are better understood, the distribution of megagrooves may be used to refine reconstructions of Pleistocene ice sheets dynamics, specifically in areas dominated by bedrock exposure.

\section{Acknowledgements}

Simon Brocklehurst and a number of anonymous reviewers are thanked for their comments, which considerably improved the manuscript. This paper is published with the permission of the Executive Director of the British Geological Survey. 


\section{References}

Anderson, RS, Hallet, B, Walder, J and Aubry, BF. 1982. Observations in a cavity beneath Grinnell glacier. Earth Surface Processes and Landforms 7: 63-70.

Augustinus, PC. 1991. Rock resistance to erosion: Some further considerations. Earth Surface Processes and Landforms $16563-569$.

Aydin, A and Basu, A. 2005. The Schmidt hammer in rock material characterization. Engineering Geology

81: 1-14.

Benn, DI and Evans, DJA. 1998. Glaciers and glaciation. Arnold: London.

Boulton, GS. 1979. Processes of glacier erosion on different substrata. Journal of Glaciology 23: 15-38.

Boulton, GS and Clark, CD. 1990. The Laurentide ice sheet through the last glacial cycle: the topology of drift lineations as a key to the dynamics behaviour of former ice sheets. Transactions of the Royal Society of Edinburgh: Earth Sciences 81: 327-347.

Bradwell, T, Stoker, MS and Krabbendam., M. 2008a. Megagrooves and streamlined bedrock in NW Scotland: the role of ice streams in landscape evolution. Geomorphology 97: 135-156

Bradwell, TB, Stoker, MS, Golledge, NR, Wilson, CK, Merritt, JW, Long, D, Everest, JD, Hestvik, OB, Stevenson, AG, Hubbard, AL, Finlayson, AG and Mathers, HE. 2008b. The northern sector of the last British Ice Sheet: Maximum extent and demise Earth Science Reviews 88: 207-226.

Bradwell, T. 2010. Keanchulish P-forms. In The Quaternary of Western Sutherland and adjacent areas: Field Guide, Lukas, S and Bradwell, T (eds.) Quaternary Research Association, London, 119-122.

British Geological Survey. 1980a. Bellingham Sheet 13, Solid Edition. England and Wales 1:50,000 series, British Geological Survey: Keyworth, Nottingham.

British Geological Survey. 1980b. Bellingham Sheet 13, Drift Edition. England and Wales 1:50,000 series, British Geological Survey: Keyworth, Nottingham.

British Geological Survey. 2008. Ullapool Sheet 101E, Bedrock Edition Scotland1:50 000 Series, British Geological Survey: Keyworth, Nottingham.

Cohen, D, Iverson, NR, Hooyer, TS, Fischer, U, Jackson, M and Moore, P. 2005. Debris-bed friction of hardbedded glaciers. Journal of Geophysical Research 110: doi:10.1029/2004JF000228.

Cohen, D, Hooyer, TS, Iverson, NR, Thomason, JF and Jackson, M. 2006. Role of transient water pressure in quarrying; a subglacial experiment using acoustic emissions. Journal of Geophysical Research 111: doi.org/10.1029/2005JF000439

Davis, GH and Reynolds, SJ. 1996. Structural geology of rocks and regions. John Wiley: New York.

De Angelis, H. 2007. Glacial geomorphology of the east-central Canadian Arctic Journal of Maps 323-341.

De Angelis, $\mathrm{H}$ and Kleman, J. 2007. Palaeo-ice streams in the Foxe/ Baffin sector of the Laurentide Ice Sheet. Quaternary Science Reviews 26: 1313-1331.

Deere, D and Miller, R. 1966. Engineering classification and index properties for intact rock. Air Force Weapons Laboratory Technical Report, AFWL-TR-65-116.

Dühnforth, M, Anderson, RS, Ward, D and Stock, G. 2010. Bedrock fracture control of glacial erosion processes and rates. Geology 38: 423 - 426.

Dyke, AS and Prest, VK. 1987. Palaeogeogaphy of northern North America, 18000 - 5000 years ago. Map 1703A. Geological Survey of Canada.

Dyke, AS, Vincent, JS, Andrews, JT, Dredge, LA and Cowan, WR. 1989. The Laurentide Ice Sheet and an introduction to the Quaternary geology of the Canadian Shield. In Quaternary geology of Canada and Greenland, Fulton, RJ (eds.) Geological Survey of Canada, 178-189. 
Fettes, DJ, Long, CB, Bevins, RE, Max, MD, Oliver, GJH, Primmer, TJ, Thomas, LJ and Yardley, BWD. 1985. Grade and time of metamorphism in the Caledonide Orogen of Britain and Ireland. In The nature and timing of orogenic activity in the Caledonian rocks of the British Isles, Harris, AL (eds.) Memoir of the Geological Society, 9: 41-53.

Finlayson, A and Bradwell, T. 2008. Morphological characteristics, formation and glaciological significance of Rogen moraine in northern Scotland. Geomorphology 101: 607-617.

Fulton, RJ. 1995. Surficial Materials of Canada, Map D1880A. Geological Survey of Canada.

Glasser, NF, Crawford, KR, Hambrey, MJ, Bennett, MR and Huddart, D. 1998. Lithological and structural controls on the surface wear characteristics of glaciated metamorphic bedrock surfaces: Ossian Sarsfjellet, Svalbard. Journal of Geology 106: 319-330.

Glasser, NF and Bennet, MR. 2004. Glacial erosional landforms; origins and significance for palaeoglaciology. Progress in Physical Geography 28: 43-75.

Goodwin, AM. 1991. Precambrian Geology. Academic Press: London.

Gordon, JE. 1981. Ice-scoured topography and its relationship to bedrock structure and ice movements in parts of Northern Scotland and west Greenland. Geografiska Annaler 63a: 55-65.

Hallet, B. 1996. Glacial quarrying: a simple theoretical model Annals of Glaciology 22: 1-8.

Haynes, VM. 1968. The influence of glacial erosion and rock structure on corries in Scotland Geografiska Annaler 50A: 221-234.

Iken, A. 1981. The effect of the subglacial water pressure on the sliding velocity of a glacier in an idealized numerical model. Journal of Glaciology 27: 407-421.

Iverson, NR. 1991a. Morphology of glacial striae: Implications for abrasion of glacier beds and fault surfaces. Geological Society of America Bulletin 103: 1308-1316.

Iverson, NR. 1991b. Potential effects of subglacial water-pressure fluctuations on quarrying. Journal of Glaciology 37: 27-36.

Jezek, K., Wu, X., Gogineni, P., Rodriguez, E., Freeman, A., Rodriguez-Morales, F. and Clark, C.D., 2011. radar images of the bed of the Greenland ice Sheet. Geophysical Research Letters 38: L01501, doi:10.1029/2010GL045519.

Krabbendam, M, Prave, AP and Cheer, D. 2008. A fluvial origin for the Neoproterozoic Morar Group, NW Scotland; implications for Torridon - Morar group correlation and the Grenville Orogen Foreland Basin. Journal of the Geological Society of London 165: 379-394.

Krabbendam, M and Bradwell, T. 2010. Medium-scale erosional landforms in the NW Highlands: the effect of bedrock properties. In The Quaternary of Western Sutherland and adjacent areas: Field Guide, Lukas, S and Bradwell, T (eds.) Quaternary Research Association, London, 103-108.

Laubach, SE and Diaz-Tushman, K. 2009. Laurentian palaeostress trajectories and ephemeral fracture permeability, Cambrian Eriboll Formation sandstones west of the Moine Thrust Zone, NW Scotland. Journal of the Geological Society 166: 349-362.

Laymon, C. 1992. Glacial geology of western Hudson Strait, Canada, with reference to Laurentide Ice Sheet dynamics. Geological Society of America Bulletin 104: 1169-1177.

Livingstone, SJ, O Cofaigh, C and Evans, DJA. 2008. Glacial geomorphology of the central sector of the last British-Irish Ice Sheet. Journal of Maps 358-377.

Mathes, F. 1930. Geologic history of the Yosemite Valley. USGS Professional Paper 160: 1-137.

Park, RG, Stewart, AD and Wright, DT. 2002. The Hebridean terrane. In The Geology of Scotland, Trewin, NH (eds.) The Geological Society, London, 45-80. 
Peacock, DCP. 2004. Differences between veins and joints using the example of the Jurassic limestones of Somerset In The initiation, propagation, and arrest of joints and other fractures, Cosgrove, JW and Engelder, T (eds.) Geological Society Special Publications 231: 209-221.

Prigmore, JK and Rushton, AWA. 1999. Scotland: Cambrian and Ordovician of the Hebridean Terrane. In British Cambrian to Ordovician Stratigraphy, Rushton, AWA, Owen, AW, Owens, RM and Prigmore, JK (eds.) Geological Conservation Review Series, 18: Chapman \& Hall, 295-315.

Rastas, J and Seppälä, M. 1981. Rock jointing and abrasion forms on roches moutonnées, SW Finland. Annals of Glaciology 2: 159-163.

Rea, BR. 1994. Joint control in the formation of rock steps in the subglacial environment. In Rock weathering and landform evolution, Robinson, DA and Williams, RBG (eds.) John Wiley, New York, 473-486.

Rea, BR and Evans, DJA. 1996. Landscapes of aerial scouring in NW Scotland. Scottish Geographical Magazine 112: 47-50.

Rea, BR and Whalley, WB. 1996. The role of bedrock topography, structure, ice dynamics and preglacial weathering in controlling subglacial erosion beneath a high-latitude, maritime ice field. Annals of Glaciology 22: 121-125.

Roberts, DH, Long, AJ, Davies, BJ, Simpson, MJ and Schnabel, C. 2009. Ice stream influence on West Greenland Ice Sheet dynamics during the Last Glacial Maximum Journal of Quaternary Science DOI: $10.1002 / j q s .1354$.

Rogers, CM and Engelder, T. 2004. The feedback between joint-zone development and downward erosion of regularly spaced canyons in the Navajo Sandstone, Zion National Park, Utah. In The initiation, propagation, and arrest of joints and other fractures, Cosgrove, JW and Engelder, T (eds.) Geological Society Special Publications 231: 49-71

Röthlisberger, $\mathrm{H}$ and Iken, A. 1981. Plucking as an effect of water-pressure variations at the glacier bed. Annals of Glaciology 2: 57-62.

Sklar, LS and Dietrich, WE. 2001. Sediment and rock strength controls on river incision into bedrock. Geology 29 1087-1090.

Smith, HTU. 1948. Giant glacial grooves in northwest Canada. American Journal of Science 246: 503-514.

Stewart, AD. 2002. The Later Proterozoic Torridonian Rocks of Scotland: their Sedimentology, Geochemistry and Origin. Geological Society Memoir, 24: Geological Society of London:

Stoker, MS and Bradwell, T. 2005. The Minch palaeo-ice-stream: NW sector of the British-Irish Ice Sheet. Journal of the Geological Society of London 162: 425-428.

Stokes, CR and Clark, CD. 1999. Geomorphological criteria for identifying Pleistocene ice streams Annals of Glaciology 28: 67-74.

Stokes, CR and Clark, CD. 2001. Palaeo-ice streams Quaternary Science Reviews 20: 1437-1457

Stone, P, Millward, D, Young, B, Merritt, JW, Clarke, SM and Lawrence, DJD. 2010. British Regional Geology: Northern England (Fifth edition). British Geological Survey: Keyworth, Nottingham.

St-Onge, MR, Lucas, SB, Scott, DJ and Bégin, NJ. 1986. Eastern Cape Smith Belt: an early Proterozoic thrust-fold belt and basal shear zone exposed in oblique section, Wakeham Bay and Cratère du Nouveau Québec map areas, northern Quebec. Geological Survey of Canada Paper, Current Research 86-1a: 1-14.

St-Onge, MR, Lucas, SB, Scott, DJ, Bégin, NJ, Helmstaedt, H and Carmichael, DM. 1988. Thin-skinned imbrication and subsequent thick-skinned folding of rift-fill, transitional-crust, and ophiolite suites in the 1.9 Ga Cape Smith Belt, northern Quebec. Geological Survey of Canada Paper, Current Research 88-1C: 1-18. 
St-Onge, M., Lucas, S. and Daigneault, R., 1993. Geology of the eastern Cape Smith Belt: parts of the Kangiqsujuaq, Cratère de Nouveau-Quebec, and Lacs Nuvilik map areas, Quebec. Geological Survey of Canada Memoir, 438, $110 \mathrm{pp}$.

Sugden, DE. 1978. Glacial erosion by the Laurentide Ice Sheet. Journal of Glaciology 20: 367-391.

Sugden, D.E. and John, B.S., 1976. Glaciers and landscape: a geomorphological approach. Edward Arnold, London, $377 \mathrm{pp}$.

Sugden, DE, Glasser, NF and Clapperton, CM. 1992. Evolution of large roches moutonnees. Geografiska Annaler. 74A: 253-264.

Viles, H, Goudie, A, Grab, S and Lalley, J. 2010. The use of the Schmidt Hammer and Equotip for rock hardness assessment in geomorphology and heritage science: a comparative analysis. Earth Surface Processes and Landforms DOI: 10.1002/esp.2040:

Vincent, JS. 1989. Quaternary geology of the southeastern Canadian Shield. In Quaternary geology of Canada and Greenland, Fulton, RJ (eds.) Geological Survey of Canada, 249-275.

Wheeler, JO, Hoffman, PF, Card, KD, Davidson, A, Sanford, BV, Okulitch, AV and Roest, WR. 1996. Geological map of Canada, Map 1860A. Geological Survey of Canada.

Winchester, JA. 1974. The zonal pattern of regional metamorphism in the Scottish Caledonides. Journal of the Geological Society of London 130: 509-524.

Woodward, J and King, EC. 2009. Radar surveys of the Rutford Ice Stream onset zone, West Antarctica: indications of flow (in)stability? Annals of Glaciology 50: 57-62.

Young, B and Lawrence, DJD. 2002. Geology of the Morpeth district: a brief explanation of the geological map sheet 14 Morpeth Explanation (England \& Wales Sheet) British Geological Survey: Keyworth.

Zumberge, JH. 1954. Glacial erosion in tilted rock layers. Journal of Geology 63: 149-158. 
TABLES

\begin{tabular}{|c|c|c|c|c|}
\hline & $\begin{array}{l}\text { Ungava, } \\
\text { Canada }\end{array}$ & $\begin{array}{c}\text { Tyne Gap, } \\
\text { England }\end{array}$ & $\begin{array}{l}\text { Ullapool, } \\
\text { Scotland }\end{array}$ & $\begin{array}{c}\text { Isle Royale, } \\
\text { Michigan }\end{array}$ \\
\hline Size of field & $20 \times 250 \mathrm{~km}$ & $3-6 \times 20 \mathrm{~km}$ & $8 \times 10 \mathrm{~km}$ & $13 \times 70 \mathrm{~km}$ * \\
\hline Spacing of megagrooves & $300-700 \mathrm{~m}$ & $100-400 m$ & $100-500 m$ & $400-800 m$ \\
\hline Length of megagrooves & $10-40 \mathrm{~km}$ & $1-4 \mathrm{~km}$ & $1-3 \mathrm{~km}$ & $2-20 \mathrm{~km}$ \\
\hline Length / width ratio of lakes & $3: 1$ to $10: 1$ & $-3: 1$ * & $\sim 5: 1$ & $\sim 7: 1$ \\
\hline Rock type(s) & $\begin{array}{l}\text { metasedimentary \& } \\
\text { metavolcanic rocks }\end{array}$ & $\begin{array}{l}\text { limestone / } \\
\text { sandstone }\end{array}$ & metasandstone & $\begin{array}{l}\text { lava flows, } \\
\text { conglomerate, } \\
\text { sandstone }\end{array}$ \\
\hline Dip of strata & $10-40^{\circ}$ & $5-20^{\circ}$ & $5-15^{\circ}$ & $10-30^{\circ}$ \\
\hline
\end{tabular}

\section{Table 1.}

Properties of megagrooves fields, in Ungava Peninsula (Quebec, Canada), Tyne Gap (northern England), Isle Royale (Michigan, USA) and Ullapool (NW Scotland).

\begin{tabular}{|c|c|c|c|c|c|c|c|c|c|}
\hline & \multicolumn{3}{|c|}{ Torridon sandstone } & \multicolumn{3}{|c|}{ Cambrian quartzite } & \multicolumn{3}{|c|}{ Morar metasandstone } \\
\hline & median & $\begin{array}{c}\text { interquartile } \\
\text { range }\end{array}$ & $\mathrm{n}$ & median & $\begin{array}{c}\text { interquartile } \\
\text { range }\end{array}$ & $\mathrm{n}$ & median & $\begin{array}{c}\text { interquartile } \\
\text { range }\end{array}$ & $n$ \\
\hline hardness ( R) & 47 & $43-48.5$ & 29 & 61 & $58-62$ & 52 & 52 & $49.5-55.25$ & 34 \\
\hline bed thickness (m) & 1.37 & $0.84-2.25$ & 64 & 0.16 & $0.13-0.27$ & 82 & 0.15 & $0.10-0.20$ & 72 \\
\hline joint spacing (m) & 2.60 & $1.48-5.58$ & 78 & 0.29 & $0.13-0.47$ & 79 & 0.43 & $0.20-0.88$ & 152 \\
\hline block volume $\left(\mathrm{m}^{3}\right)$ & 9.26 & & & 0.013 & & & 0.028 & & \\
\hline
\end{tabular}

\section{Table 2.}

Bedrock properties of Torridon sandstone, Cambrian quartzite and Morar metasandstone, NW Scotland. 


\section{FIGURES}
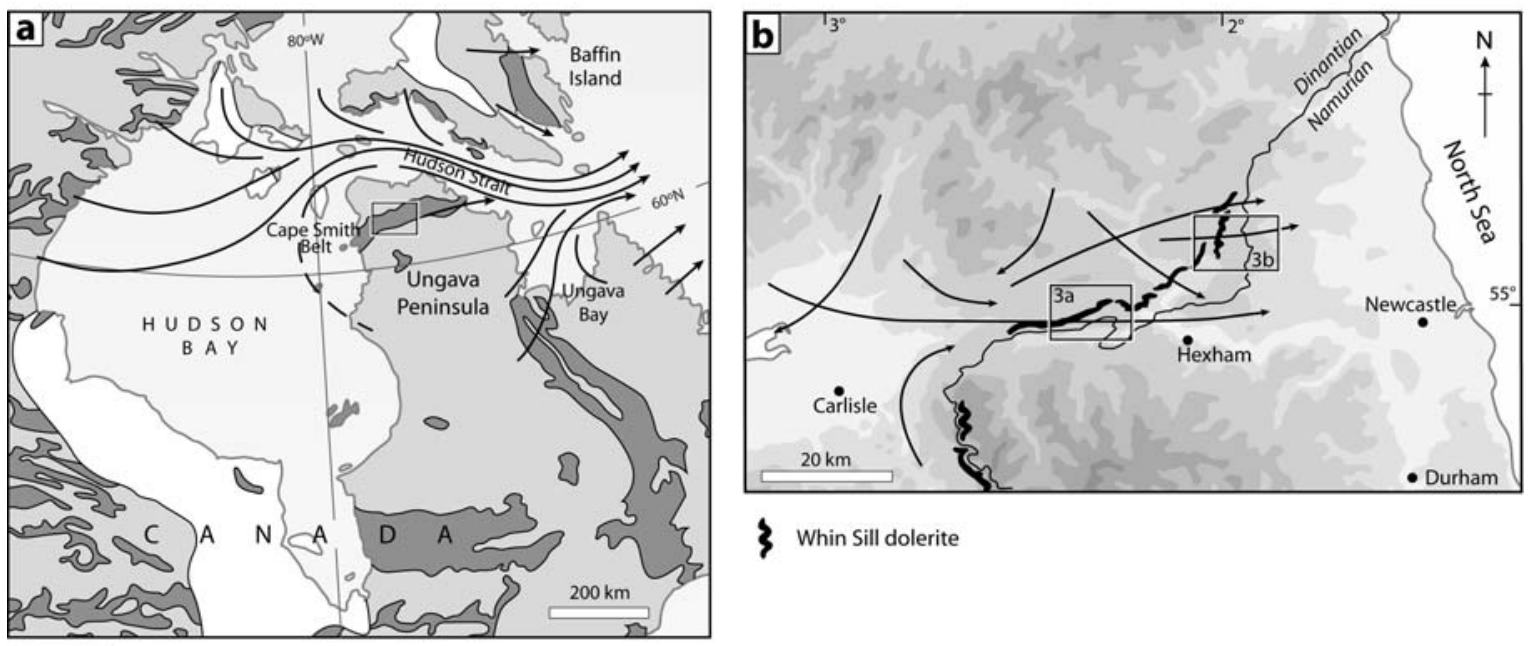

Whin Sill dolerite
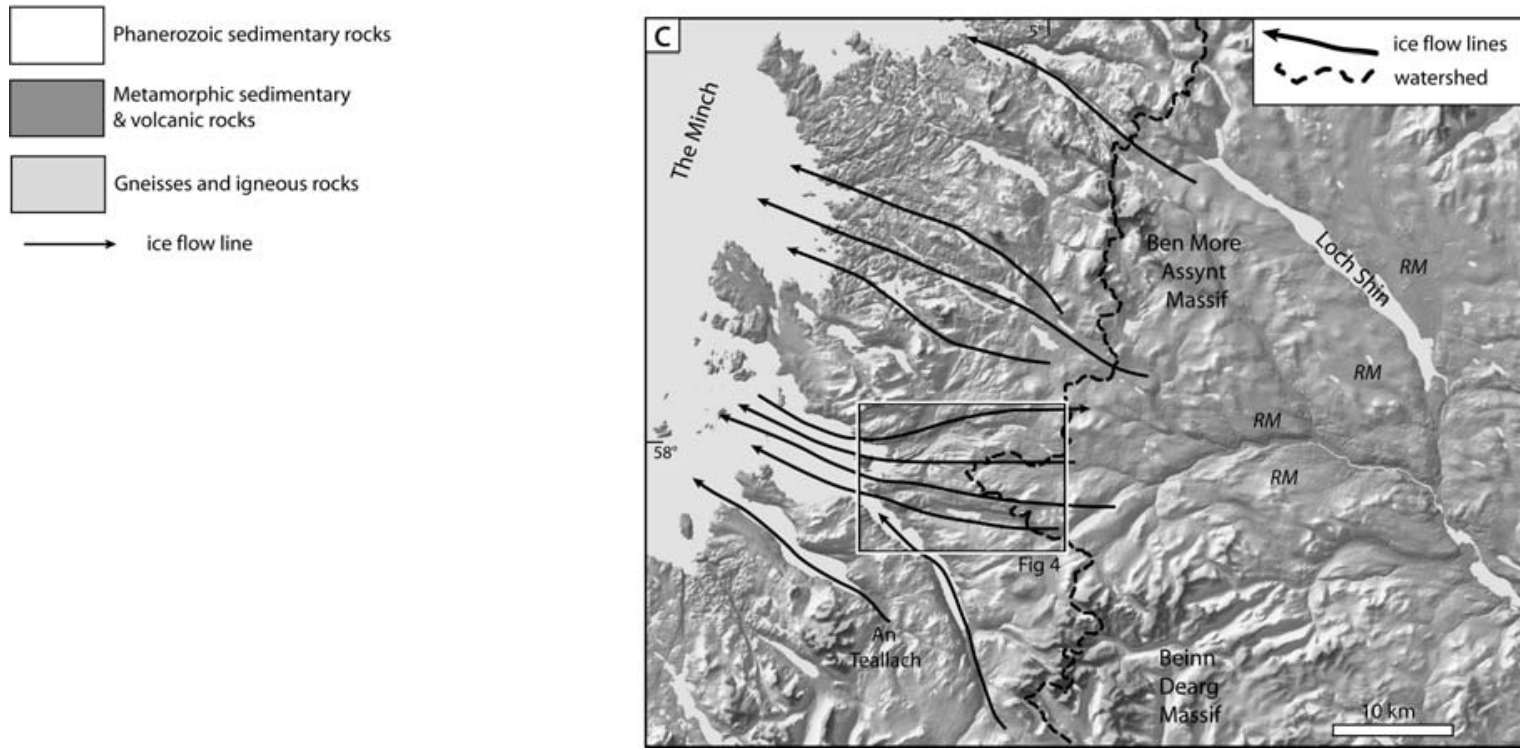

Figure 1. Location maps and setting of areas containing megagrooves.

a) Eastern part of the Canadian Shield. Occurrence of stratified metasedimentary and volcanic rocks and of crystalline basement rocks is shown, after Dyke et al. (1989). Postulated ice-flow lines after Dyke \& Prest (1987). Box indicates position of Figure 2. b) Location map of the Tyne Gap area in Northern England. Outcrop of the Whin Sill dolerite and the Dinantian/Namurian boundary is shown to indicate overall swing in strike (after Stone et al., 2010). Main ice-flow lines after Livingstone et al. (2008). Location of Figures $3 \mathrm{a}$ and $3 \mathrm{~b}$ is indicated.

c) NEXTMap shaded relief map of the Northern Highlands, showing setting of the Ullapool megagroove field. Box indicates position of Figure 4a. Ice-flow lines are hypothetical, but based upon streamlined bedforms and overall topography. During the Last Glacial Maximum the ice divide may have been positioned well east of Loch Shin (Bradwell et al., 2008b). RM = location of rogen moraines after Finlayson and Bradwell (2008). NEXTMap Britain elevation data from Intermap Technologies 


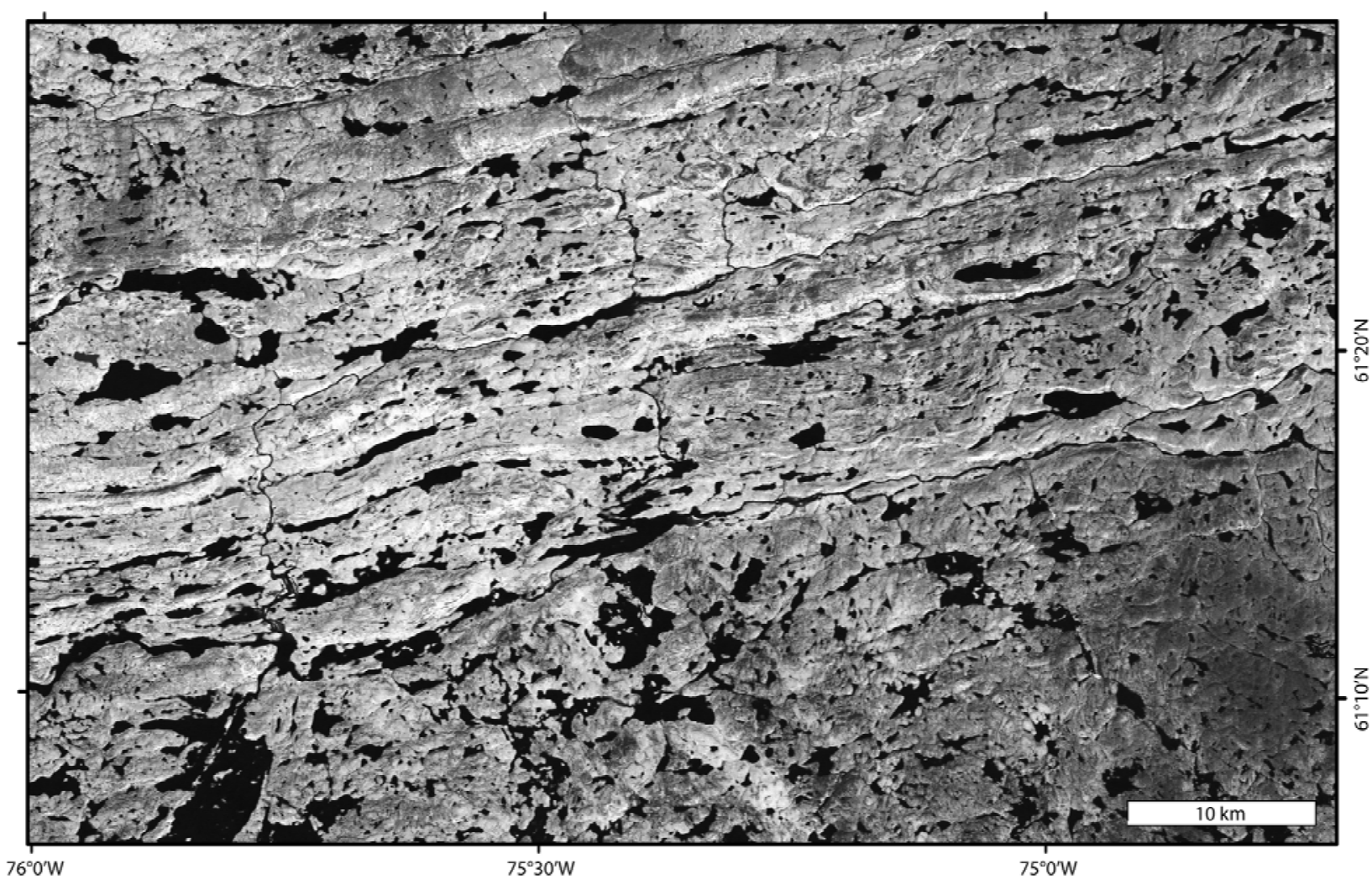

Figure 2. Megagrooves in the Cape Smith Belt on the Ungava peninsula, northern Quebec, Canada. Landsat image, band 8. Note the absence of elongate lakes and ridges in the southern third of the image which comprises gneisses of the Superior Province. For location see Figure 2. 

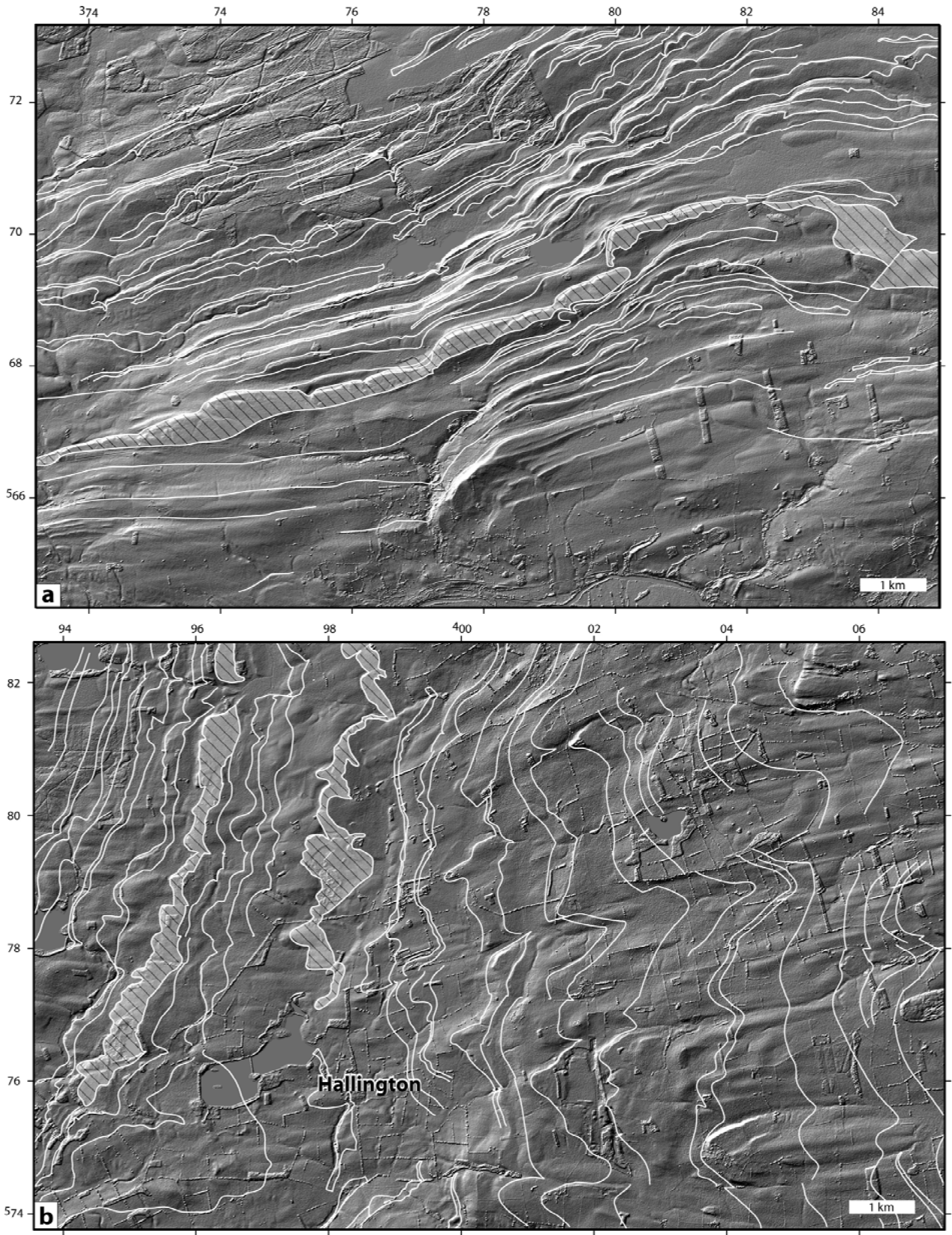

Figure 3. a) NEXTMap DTM shaded relief image of the Tyne Gap area, northern England. Ice flow was to the east. White lines are geological boundaries of the main sandstone units; dolerite (Whin Sill) is hatched. These lines indicate the overall strike. Geological boundaries in complicated faulted areas have been removed for clarity.

b) Similar image of the Hallington area: ice flow was to the east, as indicated by drumlins and crag-and-tails. NEXTMap Britain elevation data from Intermap Technologies. Geological boundaries after British Geological Survey (1980a). 

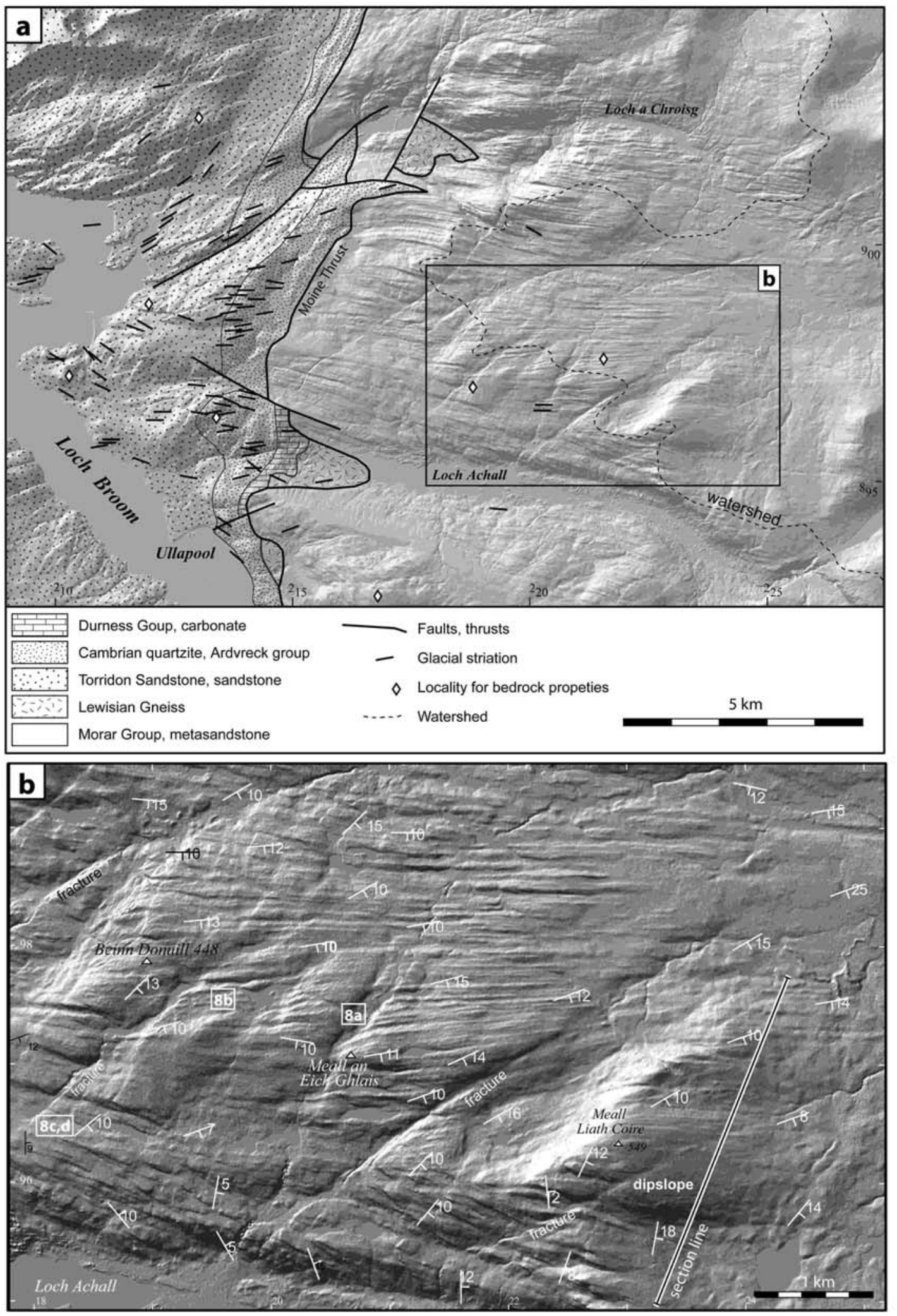

Figure 4. NEXTMap DTM shaded relief image, showing the field of megagrooves east of Ullapool.

a) Overview, showing simplified bedrock geology after British Geological Survey (2008).

b) Detail of Meall Liath Choire area. Strike-and-dip symbols for bedding superposed. Note high concentration of megagrooves subparallel to bedrock strike in the upper left part of the image. The hill slope SE of Meall Liath Coire is subparallel to bedding (a dipslope) and contains only few megagrooves. Note development of deep meltwater channels along NE-SW trending fractures, independent from megagrooves. Locations of photos of Figure 8 are indicated. Line of cross section of Figure 9 is indicated. NEXTMap Britain elevation data from Intermap Technologies 


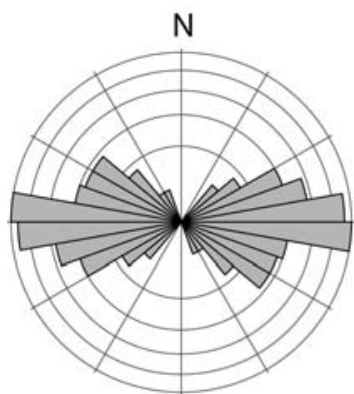

a) Glacial Striae

$n=112$, max frequency $=22$, resultant $=89^{\circ}$

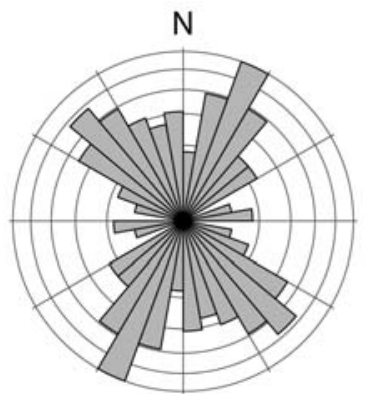

b) Joints - Torridon

$n=76$, max frequency $=16$

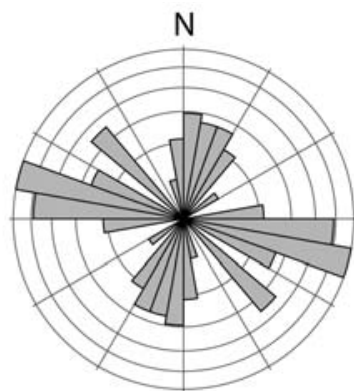

c) Joints - Quartzite

$n=80$, max frequency $=23$,

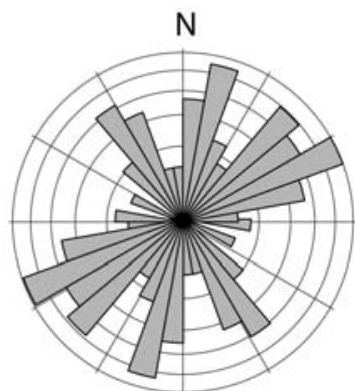

d) Joints - Morar

$n=127$, max frequency $=15$

Figure 5. Rose diagrams of a) glacial striae in the Ullapool area; b) joint trends in the Torridon sandstone; c) joint trends in the Cambrian quartzite; d) joint trends in the Morar metasandstone. All rose diagrams are area-scaled with a bin size of $10^{\circ}$.
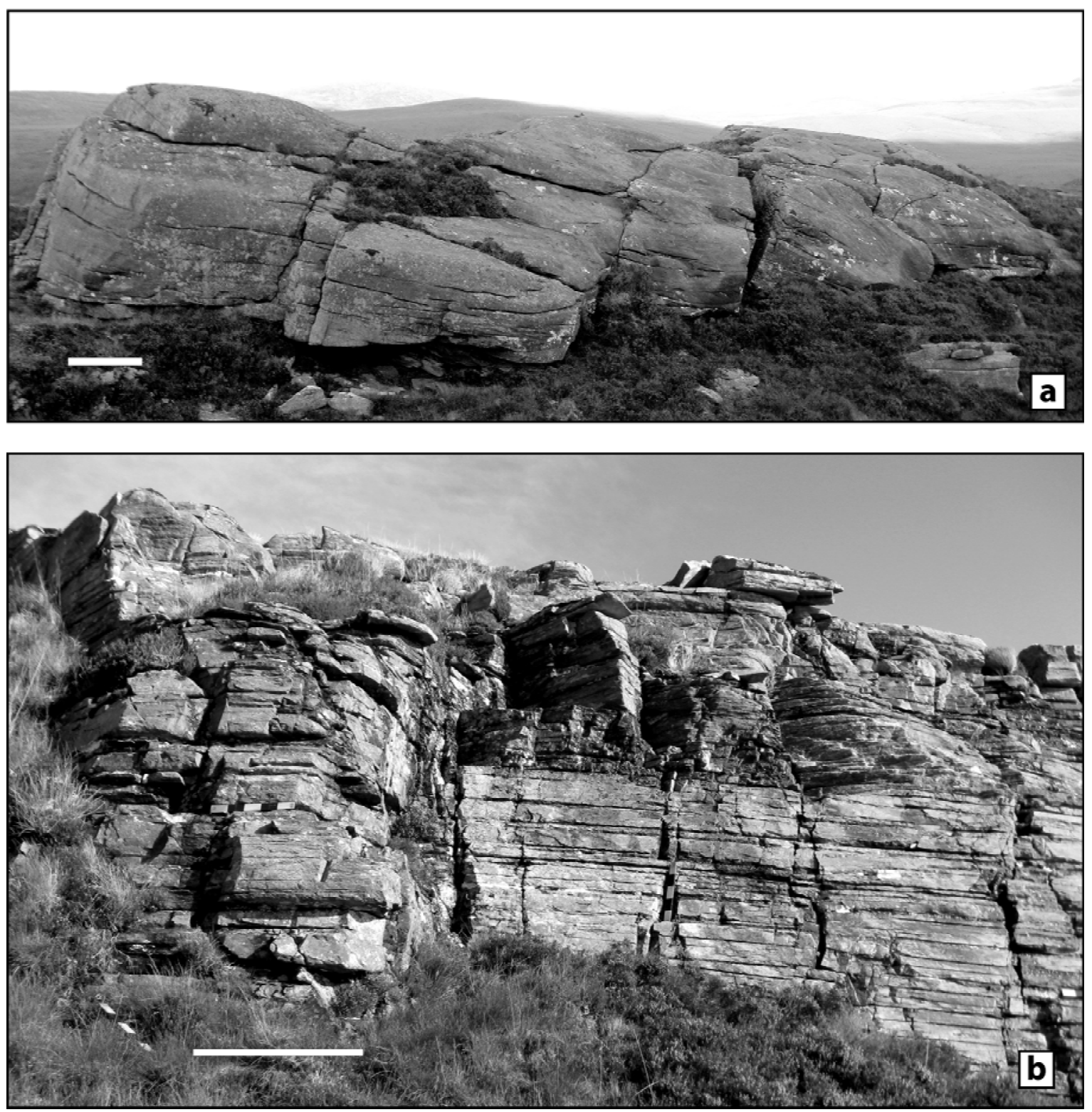

Figure 6. Examples of Torridon sandstone and Morar metasandstone. Scale bar is $1 \mathrm{~m}$ long.

a) Torridon Sandstone, rounded roche moutonnée, transitional to whaleback, view to north; ice flow to left (west), $3 \mathrm{~km}$ NNE of Ullapool, [NH 2978 6578].

b) Morar metasandstone with NE-SW trending joint set, view to NE; 4 km SSE of Ullapool, [NH 6782 1997]. 


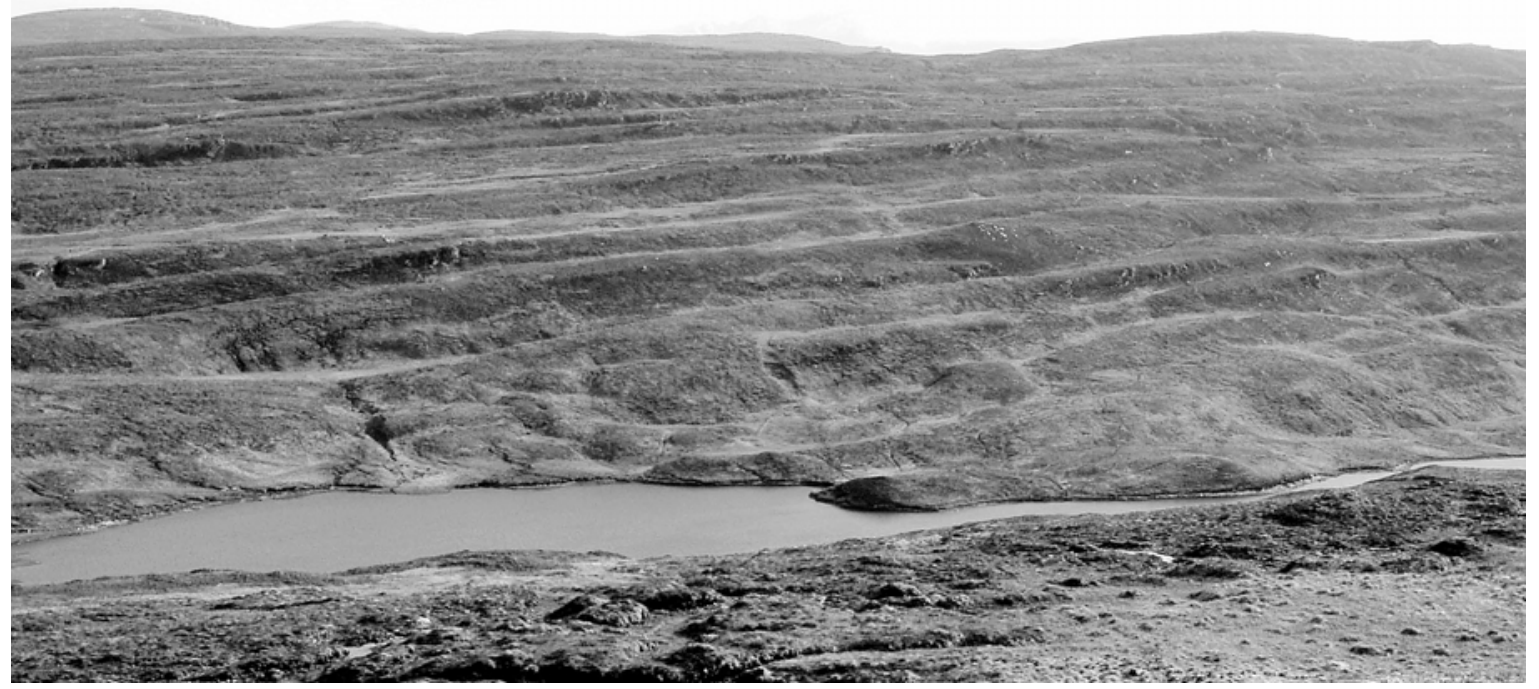

Figure 7 Overview of asymmetric megagrooves, view to the south from Meall Odhar across Loch a Chroisg (See Figure 4 for location). Ice flow direction was to the right (west). Width of view c. 2 km. BGS Photo 595952
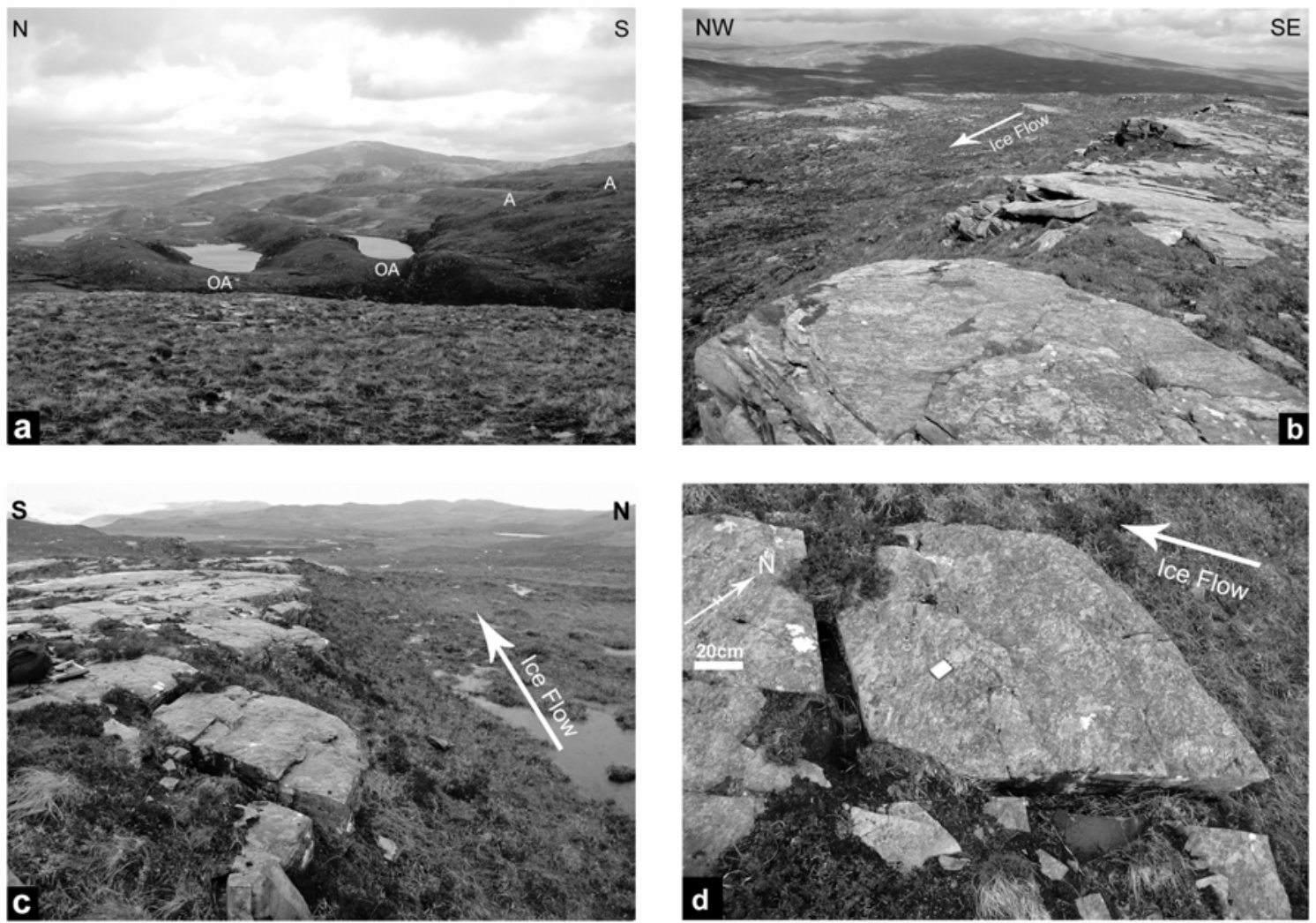

Figure 8

Field photographs of megagrooves. Locations indicated on Figure $4 \mathrm{~b}$.

a) A series of megagrooves viewed to the east; palaeo-ice flow direction is towards the viewer. $A=$ asymmetric megagrooves; $\mathrm{AL}=$ asymmetric megagrooves with lakes. Spacing of megagrooves is $60-100 \mathrm{~m}$. Northern slope of Meall an Eich Ghlass, [NH 206 975]; BGS Photo 595912.

b) Asymmetric megagroove, looking ENE. Rock step is c. $3 \mathrm{~m}$ high; width of flat floor is c. $60 \mathrm{~m}$. Arrow shows palaeo-ice flow direction. About 1 km ESE of Beinn Donuill, [NH 2040 9766]; BGS Photo P595903.

c) Asymmetric megagroove, looking east. Rock step is c. $1 \mathrm{~m}$ high. Note absence of scree, and conjugate joint pattern. Note large block (see Figure 4d). 1 km north of Loch Achal; [NH 1817 9653]; BGS Photo 595885.

d) Large block ( $\sim 1.5$ by $1 \mathrm{~m} ; \sim 80 \mathrm{~cm}$ thick); plan view, north arrow shown. Note slight anticlockwise rotation out of original position. Arrow shows palaeo-ice flow direction. Same location as Figure 4c; BGS Photo 595884. 


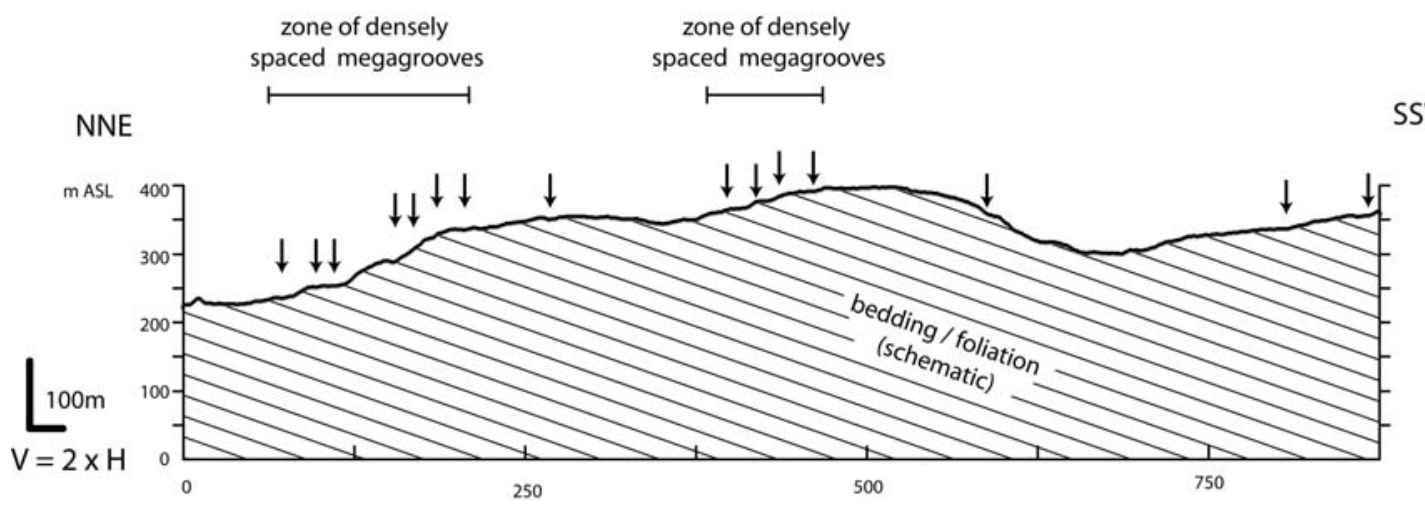

Figure 9: Cross-section, trending NNE-SSW; ice flow was towards the viewer (see Figure $4 \mathrm{~b}$ for location). Arrows indicate location of megagrooves, as seen on DTM. Dip of bedding/foliation is averaged and shown schematic. $2 x$ vertical exaggeration.
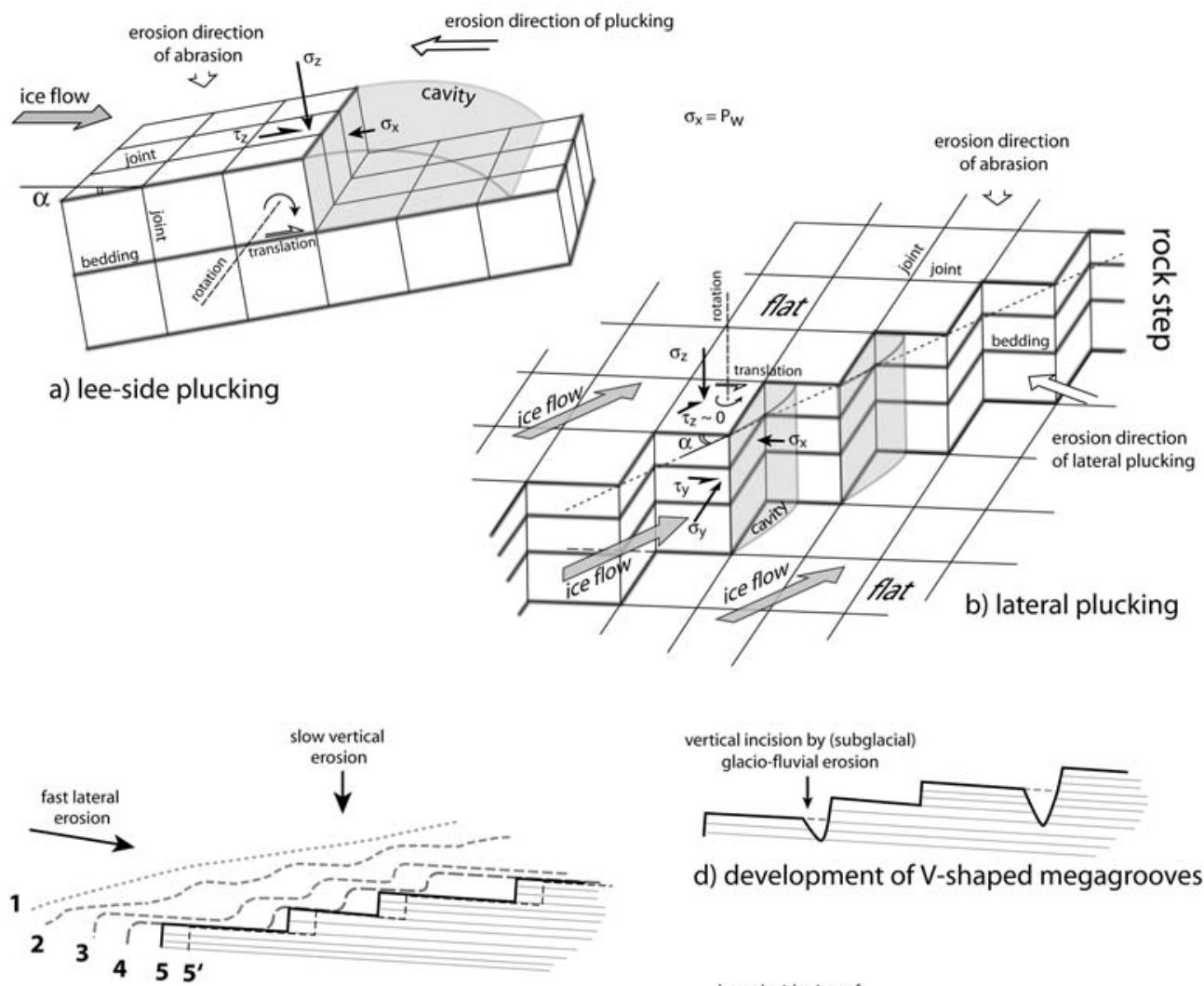

d) development of V-shaped megagrooves

c) development of assymetric megagrooves

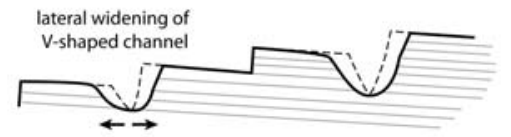

e) development of parabolic megagrooves

Figure 10: a) Schematic block diagram of a classic lee-side plucking, showing joints and inferred shape of cavity. Lateral stresses are not shown. After Rea \& Whalley (1996). $\sigma_{a}$ indicates normal stress, $\tau_{\mathrm{a}}$ shear stress, acting on surfaces $\mathbf{a}$. The top surface is marked as a, $\mathbf{c}$ is the surface abutting the cavity, and $\mathbf{b}$ the third, vertical surface. Normal stress $\sigma_{\mathrm{c}}$ is equal to the water pressure in the cavities. Note that there is no shear stress in the cavities. Frictional drag not shown.

b) Schematic block diagram of an asymmetric megagroove with lateral plucking, showing relation of bedding/foliation, the conjugate joint set and the megagroove. Inferred palaeo-ice flow, block motion and direction of erosion are indicated.

c) Model of development of an asymmetric megagroove. Starting point can either be a smooth slope (1) or an incipient stepped landscape (2). A steady state bed may develop (5 to 5'). Ice flow towards viewer.

d) Model of development of a $V$-shaped megagroove from an asymmetric megagroove. Erosion will focus in the lowest point of the megagroove. Ice flow towards viewer.

e) Model of development of a parabolic megagroove from a V-shaped megagroove. Lateral erosion by lateral plucking widens the initial V-shaped groove. Ice flow towards viewer.

For further explanation, see text. 